Original Research Paper

\title{
Heterogeneities and Intra Sand-Body Compartmentalization in Late Oligocene Delta-Front Deposit, Niger Delta, Nigeria
}

\author{
Raphael Oaikhena Oyanyan and Michael Ndubuisi Oti \\ Department of Geology, P.M.B. 5323, University of Port Harcourt, Nigeria
}

\author{
Article history \\ Received: 28-03-2015 \\ Revised: $14-03-2016$ \\ Accepted: 16-03-2016 \\ Corresponding Author: \\ Raphael Oaikhena Oyanyan \\ Department of Geology, P.M.B. \\ 5323, University of Port \\ Harcourt, Nigeria \\ Email: raphoyanyan@yahoo.com
}

\section{Introduction}

Early water breakthrough, dry holes and early field abandonment are serious challenging situations in the exploration and production of hydrocarbon. The bypassed of oil zones in a well after huge investment on the various stages of exploration, field appraisal/development and flow station infrastructures etc, can be considered an unintentional economic sabotage. One of the geologic reasons that have been adduced for these ugly situations by some authors (Smalley and Muggeridge, 2010; Morris et al., 2012;

\begin{abstract}
This paper presents the study of the heterogeneity in lithofacies, porosity, permeability, mineral grain density, pore-throats sizes and hydraulic rock types and the intra sand-body compartmentalization in cored delta-front deposit of Greater Ughelli depobelt of Niger Delta. Sedimentological study of core samples results in the identification of nine lithofacies and the interpretation of environments of deposition as mainly proximal and distal delta-front mouth bar. The sand unit indicates moderate to excellent reservoir quality with core porosity between 16.2 and $29.5 \%$ and permeability between 16.8 and 7,560 md. Dykstra-Parsons core permeability distribution coefficient of 0.97 indicates that the studied reservoir sand-body is vertically highly heterogeneous, with high potential for vertical intra sand-body compartmentalization. Graphical cluster analysis of Flow Zone Indicators (FZI) led to the identification of nine Hydraulic Flow Units (HFU) with distribution controlled by depositional facies. The prediction of permeability, porethroats (r35) and flow zone indicator values of the reservoir in an uncored-well using predictive mathematical models developed with multiple regression analysis enabled the inter-well correlation of hydraulic flow units and indicates lateral continuity of reservoir compartments. An intra sand-body compartmentalization evaluated with core permeability values, Winland r35 coefficients and flow zone indicators was corroborated with formation pressure data analysis. Results show that the studied delta front-mouth bar reservoir is vertically compartmentalized by intercalated shales. Fractures in over-pressured zones were found to reduce vertical reservoir fluid compartmentalization by intercalated shales. However, reduction in reservoir pressure due to hydrocarbon production can result in dynamic compartmentalization and consequently, reduction in hydrocarbon recovery.
\end{abstract}

Keywords: Delta Front, Heterogeneity, Rock Types, Compartmentalization, Flow Zone Indicators, Winland r35, Multiple Regression
Fox and Bowman, 2010) is reservoir compartmentalization caused by heterogeneities (Lasseter et al., 1986).

Reservoir heterogeneity is lateral and vertical variations in rocks properties. Proper identification and knowledge of various scales of reservoir heterogeneities is necessary because different scale of heterogeneities have different impact on reservoir performance, production forecasts and hydrocarbon recovery (Singh et al., 2013). Authors such as (Weber, 1986; Lasseter et al., 1986) gave various scales of 
reservoir heterogeneities that can impact reservoir fluid flow. Howell et al. (2008) defined the key causes of heterogeneity within progradational shallow-marine reservoirs. Ainsworth (2010) described how the stratigraphic and depositional sedimentary heterogeneities can result in reservoir compartmentalization.

A reservoir compartment is a body of rock with good internal hydraulic communication and porosity, which is surrounded by low permeability rock such as shale or mudstone (Rahimpour-Bonab et al., 2014). While reservoir compartmentalization as defined by Jolley et al. (2010) is the division of a reservoir into partial or full pressure isolated compartments by faults, permeability or porosity pinch-outs, folding, shale streaks, barriers or other factors. It can simply be defined as limitation on the ability to produce hydrocarbons resulting from permeability barriers within a field (Morris et al., 2012). Intra sand-body compartmentalization, according to Ainsworth (2010), is the one caused by heterogeneities within reservoir sandbody. The heterogeneities cut across both the medium and small scale zonations (Lasseter et al., 1986) and baffles within genetic units such as inclined or dipping shales on the foresets of mouth bars (Weber, 1986). Compartmentalization is evidenced by vertical and lateral variation in reservoir fluid pressure in a well and between different wells draining the same reservoir respectively, as well as variation of fluid contacts in a reservoir at different well locations (Shaker, 2008; 2012).

Niger Delta oil fields are characterised by structural and depositional/stratigraphic heterogeneities that impact hydrocarbon production (Short and Stauble, 1967; Weber, 1971; Doust and Omatsola, 1990). Some of the oil fields are matured and on the verge of being abandoned due to low economic viability. It is necessary before a field is painfully abandoned or sold, reservoir compartmentalization is properly analysed for via the study of various scales of reservoir heterogeneities. Therefore, the aim of this paper is: (1) to characterised reservoir flow properties and document the influence of sedimentary heterogeneities on petrophysical properties that can lead to subsurface fluid compartmentalization, (2) differentiate reservoir flow units from intra-reservoir flow barriers to achieve vertical reservoir sand-body layering or scheme that can be used for adequate well development/completion and production optimization and (3) prove the existence of intra sand-body compartmentalization with pressure data analysis.

To achieve the aforementioned aims, the components of reservoir heterogeneity evaluated in this study include lithofacies, porosity, permeability and pore-throat sizes (r35), flow zone indicators and hydraulic rock types.

\section{Study Area and Regional Geologic Setting}

The study area, Gabi-Eke oil field, is a producing field located in the Greater Ughelli depobelt of the Niger Delta, a major petroleum producing province with great importance to economy of Nigeria, situated on the West Coast of Africa, between Latitude $3^{0}$ and $6^{0} \mathrm{~N}$ and Longitude $5^{0}$ and $8^{0} \mathrm{E}$ (Fig. 1). The study area is approximately $65 \mathrm{~km}$ from Port Harcourt, Rivers state, Nigeria. The field is about $164.16 \mathrm{~km}^{2}$ in size with oil, condensate and gas producing wells. It is bounded in the north by a major growth fault that has three adjoining antithetic growth faults. Down-dip the major growth faults are up to eight syndepositional synthetic growth faults with their associated rollover anticline that form fault-dip closure. The wells used in this study are indicated in Fig. 1 with red coloured ring.

The studied reservoir sediments were recovered from the Agbada Formation, which is one of the three lithostratigraphic units in the Niger Delta basin (Short and Stauble, 1967). The Agbada Formation has a maximum thickness of $4000 \mathrm{~m}$ and characterized by paralic to marine coastal and fluvial-marine deposits mainly composed of sandstones and shale organized into coarsening-upward of flap cycles. Underlying the Agbada Formation is the Akata Formation, with maximum thickness of $6500 \mathrm{~m}$ and mainly made up of overpressured marine shale with thin silt and sandy interbeds. On top the Agbada Formation is the Benin Formation, which has a maximum thickness of $2000 \mathrm{~m}$ and consists of continental and fluvial sands, gravel and back swamp deposits.

The tectonic setting of Niger Delta is connected to coastal and ocean ward part of the southern Benue Trough. The tectonic evolution of Benue Trough and Niger Delta are well documented in Niger Delta geologic literatures (Short and Stauble, 1967; Doust and Omatsola, 1990; Reijers, 2011; Nwajide, 2013). Meanwhile, the structural patterns indicate that the delta comprises six depobelts that include the Greater Ughelli where the study area is located. The depobelts are growth fault bounded sedimentary units that succeed each other in a southward direction (Doust and Omatsola, 1990).

\section{Dataset and Methods}

The data acquired for this study include wireline logs (Gamma, resistivity, sonic, bulk density and neutron) (Fig. 2), $43 \mathrm{~m}$ cores of D3 reservoir depth interval in well Gabi 55, core mineral grain density values, core porosity and permeability values; and pressure data.

Core samples were examined for lithology, sediment texture (grain size and shape), trace fossils, macro-diagenetic features and primary sedimentary structures for the identification of lithofacies. 

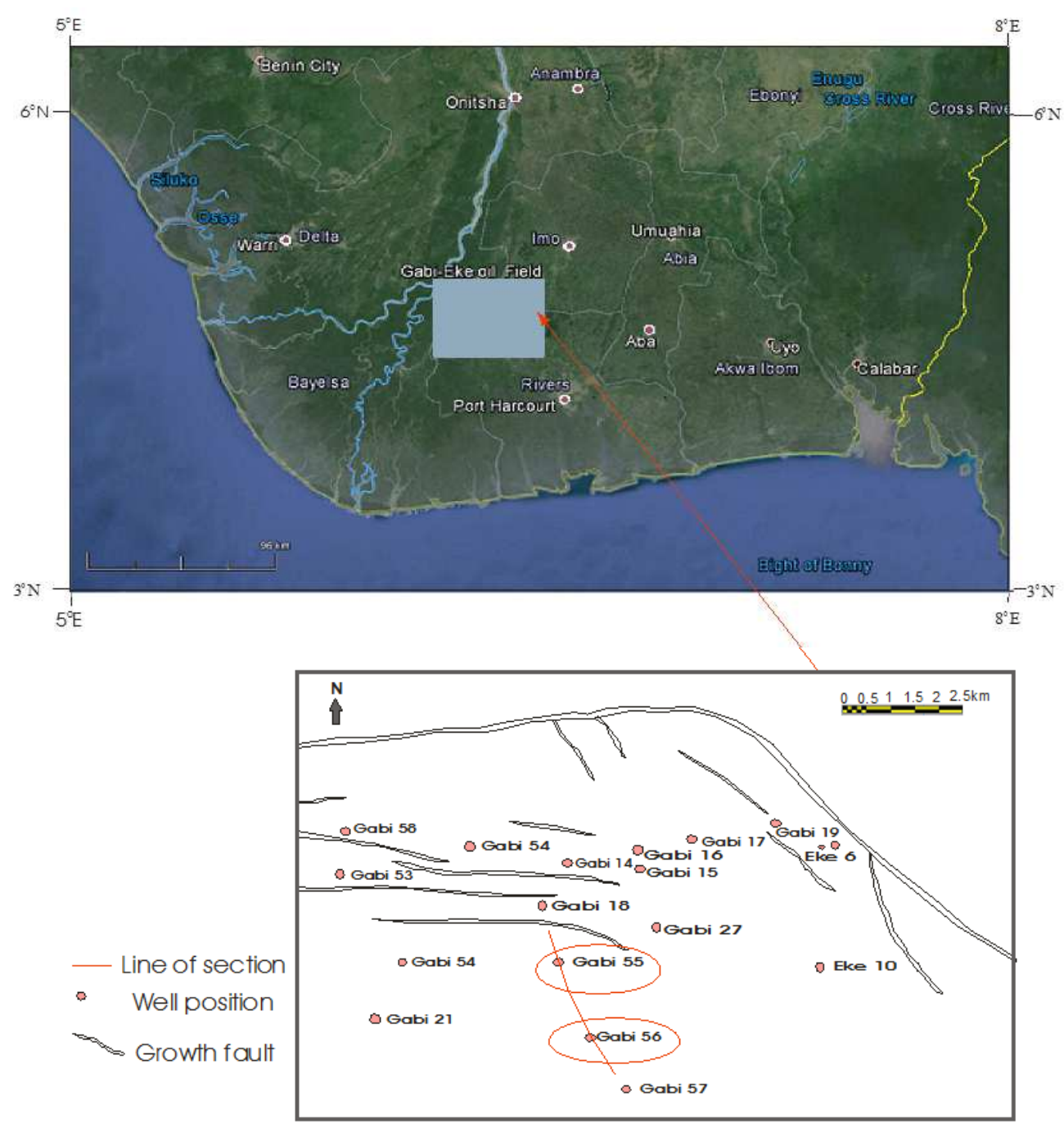

Fig. 1. Study field location map showing well locations and growth faults

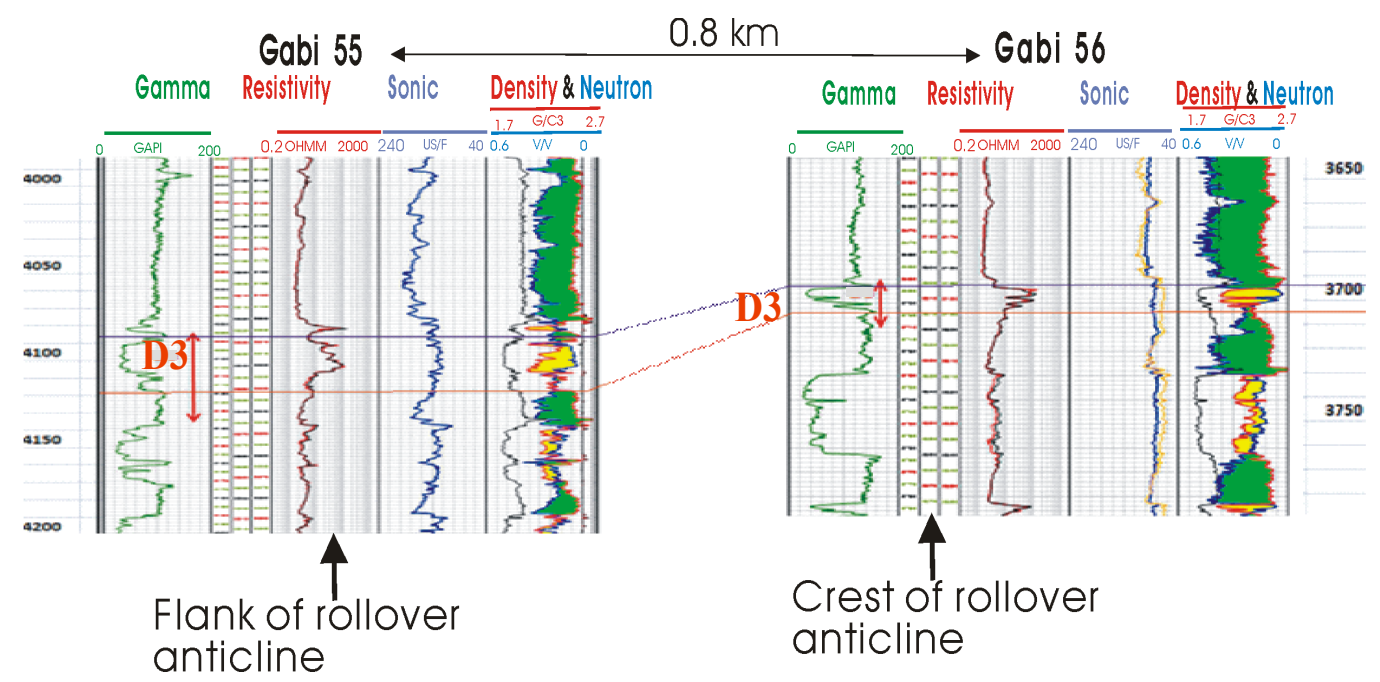

Fig. 2. Shows Wireline log character of D3 reservoir sands 
Biogenic textural heterogeneity/degree of bioturbation in cores was classified with Bioturbation Index (BI) of Taylor and Goldring (1993). The combination of wireline $\log$ motifs and lithofacies characteristics enabled the identification of environments of deposition.

Histograms/cumulative frequency distribution and cross-plot analysis of petrophysical data were used to evaluate petrophysical heterogeneity of the studied reservoir sand-body. Cross-plot analysis gives visual clues to the presence of heterogeneity in petrophysical data (Fitch et al., 2015).

Permeability heterogeneity was quantified using coefficient of permeability variation of Dykstra and Parsons (1950) as explained by Jensen et al. (2000). The coefficient of permeability variation, called the DykstraParsons coefficient $\left(V_{d p}\right)$, is defined as follows:

$V_{d p}=\left(k_{50}-k_{84} \cdot 1\right) / k_{50}$

Where:

$k_{50}=$ Median reservoir permeability.

$k_{84} \cdot 1=$ Permeability at the 84.1 percentile

The Dykstra-Parsons coefficient ranges from a minimum of 0 (pure homogeneous) to a maximum of 1.0 (heterogeneous), with most reservoirs falling within $V_{d p}$ $=0.5$ to 0.9 .

Pore-throat radius at $35 \%$ mercury saturation was derived from core porosity and permeability using Winland equation published by (Kolodzie, 1980; Pittman, 1992; 2001):

$\log R 35=0.732+0.588 \log K_{\text {air }}-0.864 \log \phi_{\text {core }}$

where, R35 is the pore aperture radius corresponding to the 35 th percentile of mercury saturation in a mercury porosimetry test, Kair is the uncorrected air permeability (in md) and $\phi$ is porosity (in \%).

Rock typing based on Reservoir Quality Index (RQI)Flow Zone Indicator (FZI) method of Amaefule et al. (1993) was applied in the determination and classification of hydraulic rock types and flow units in D3 reservoir sands. The hydraulic rock type classification provides a physical measure of the rock flow and storage properties at current conditions-i.e., reflecting the current pore structure as modified by diagenesis (Rushing et al., 2008).

Flow unit is the volume of rock that shows similar geological and petrophysical properties, which, in turn, are clearly different from other rock volumes (Rushing et al. 2008). FZI is a function of mineralogy and texture; and reflects the relationship between pore throats; and the flow unit with the highest FZI has the largest relationship between the pore throats
(Torres et al., 2010). FZI was obtained with the following Equations 3-5:

$F Z I=R Q I / P H I Z$

$R Q I$ is a close approximation of the average hydraulic radii (pore throat):

$R Q I($ microns $)=0.0314 v^{-}(K / \Phi)$

$\mathrm{PHIZ}=\varnothing \mathrm{Z}=(\varnothing / 1-\varnothing)$

Where:

$F Z I=$ Flow zone indicator

$R Q I=$ Rock quality index

$P H I Z=$ Zone porosity $(\varnothing Z)$

$\varnothing \quad=$ Core porosity

Graphical clustering of FZI values was used to identify hydraulic flow units.

To achieve the inter-well correlation of Hydraulic Flow Units (HFU), reservoir compartments, permeability, pore throats (R35) and Flow Zone Indicator (FZI) values of D3 reservoir to a well with no core measurements data (well Gabi 56), predictive mathematical models were developed with multiple regression analysis and used to predict the petro physical properties of the well. The dependent variables are permeability, R35 and flow zone indicators, while bulk density and gamma ray log data were used as predictor or independent variables because the two parameters reflect variations in permeability and porosity (Dewan, 1983). The theory of multiple regression analysis can be found in (Draper and Smith, 1998; Mohaghegh et al., 1997; Wendt et al., 1986; Orlov, 1996).

Pressure is one of the reservoir fluid properties commonly used to assess the level of compartmentalization and identify the position of compartment boundaries during the appraisal and production of petroleum reservoirs (Jolley et al., 2010). Therefore the evaluation of intra sand-body compartmentalization with the above mention methods was corroborated with pressure-depth (p-d) profile plotting. The methods of Shaker (2012) was adopted to infer the sealing capacities of intra-reservoir shales. According to him, seal capacity can be inferred from pressure shift between the consecutive compartments. Competent seal is represented by positive shift, whereas negative shift reflect breach due to structural failure (e.g., fault and fractures). 


\section{Results}

\section{Lithofacies Heterogeneity}

Nine lithofacies were identified within the D3 reservoir sands cored only in well Gabi 55 (Fig. 2) based on lithology, texture and sedimentary structures. The lithofacies are: (i) Inter-bedded silty shale and finegrained sandstone, (ii) Massive coarse- to fine-grained sandstone, (iii) Conglomerate/Gravelly sandstone, (iv) Ophiomorpha burrowed fine- to coarse-grained sandstone, (v) Cross-stratified fine- to medium-grained sandstone, (vi) Mud draped high angle cross-laminated sandstone, (vii) Inclined fine-grained sandstone and shale heteroliths, (viii) Inclined inter-laminated sand and shale with convolute structures and (ix) Massive shale/silstone and shale couplets. Detailed descriptions of these lithofacies and the sub-environments of deposition have been done by Oyanyan and Oti (2015a). The characteristics and interpretations of the lithofacies are however summarized in Table 1.

Table 1. Description and interpretation of lithofacies identified in D3 Reservoir sands

Lithofacies
Inter-bedded silty shale
fine-grained sandstone
Massive coarse-to
fine-grained sandstone
Conglomerate/
Gravelly sandstone

Ophiomorpha burrowed fine- to coarse-grained sandstone

Cross-stratified fine-to medium-grained sandstone

Mud draped high angle cross-laminated sandstone

Inclined fine-grained sandstone and shale heteroliths

Inclined inter-laminated sand and shale with convolute structures

Massive shale/siltstone and shale couplets

Description

Shale with intervals of $\mathrm{mm}$-cm thick siltstone and ripple laminated sandstone that fines upward, bioturbated (BI: 0-3) and shaly. Some sideritic nodules in the shale. Mix current and wave ripples, flaser and lenticular beddings and rare fractures (Fig. 3a).

$0.6 \mathrm{~m}$ thick, fines upward and underlain by an erosive base with basal lags. Poorly to moderately sorted and micaceous (Fig. 3b). Very coarse to granules and pebbles, with mica flakes. Poorly sorted. Pebbles sub-rounded to well rounded. Bioturbation $(\mathrm{BI}=1)$ : Rare Ophiomorpha burrows (Fig. 3c). Fairly massive with sporadic faint crossstratifications. Moderately to commonly bioturbated (BI = 3-4) by Ophiomorpha burrows (Fig. 3d).

Upward cleaning sandstone. Lamina-sets are 1.0 to $2.5 \mathrm{~cm}$ thick. Rare hummocky lamination. Well-sorted and micaceous. Bioturbation $(\mathrm{BI}=0-2)$ : Ophiomorpha and rare Diplocraterion burrows (Fig. 3e).

Very fine grains, well sorted and micaceous. High angle cross-laminations with foresets draped by mud flasers to occasional $2-4 \mathrm{~cm}$ thick shaly mud. Rare hummocky cross laminations (Fig. 3f). Sporadic bioturbation $(\mathrm{BI}=1-2)$ by Planolites and localized Chondrites.

Sand dominated heteroliths. The sand units are characterized by small scale hummocky and swaly cross laminations and rare load structures. Bioturbation by $(\mathrm{BI}=1-2)$ by Planolites, rare Phycosiphon, Lockeia, Fugichnia Palaeophycus, rare Synaeresis crack and rare Cylindrichnus (Fig. 3g). Inclined inter-lamination with convolute structures and basal upward-concave sharp contact (Fig. 3h).

Massive shale, grading upward to lenticularwavy but rarely contorted siltstone-shale couplets and rare fractures (Fig. 3i).
Depositional processes/interpretation

Clay deposition from suspension settling during slack water condition and sand deposition during periods of higher currents. Sharp based clean sandstone intervals are tidal washover sandstone. Sideritic nodules indicate reducing condition in deep subaqueous condition.

Rapid deposition. Small thickness, poor to moderate sortedness and erosive base with basal lags are typical of marine transgression. Quick gravity flow deposition and wave reworking processes that remove the finer matrix. Mica flakes indicate constant and high rate of sediment supply to shelf from river. Abundant Ophiomorpha burrows reflect deposition in oxygenated, high energy and shallow water depositional setting. Typical of proximal delta front environment.

Product of two-dimensional dunes migration in unidirectional flows of relatively low velocities. Rare hummocky lamination reflects occasional wave influence.

Migration of sinuous crested ripples with mud deposition on the lee slope during periodic drops in depositional current. The thick mud inter-beds represents fluid mud deposition on clinoform surfaces. Rare hummocky cross lamination indicates occasional influence of storm waves.

Deposition on an inclined surface by tidal current of fluctuating strength. Load structure is an evident of rapid deposition. Hummocky and swaley cross-laminations reflect the influence of storm waves and indicate deposition between storm and fair-weather wave base. Synaeresis crack is an evident of salinity fluctuation. High angle inclination and convolute lamination indicate rapid deposition from storm generated hyperpycnal flow on an inclined deposition surface of a deltaic setting.

Rapid deposition of suspended load in a low energy environment. Fracture is an evidence of an overpressure condition. 


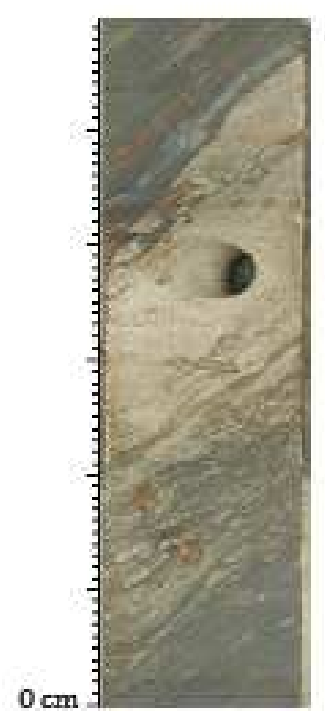

(a)

(f)

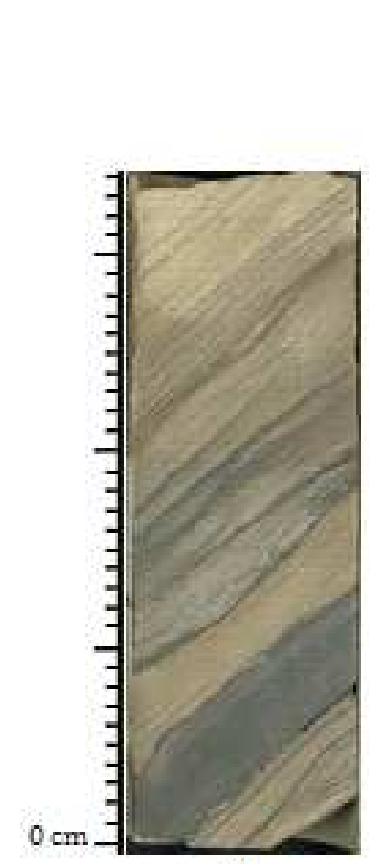

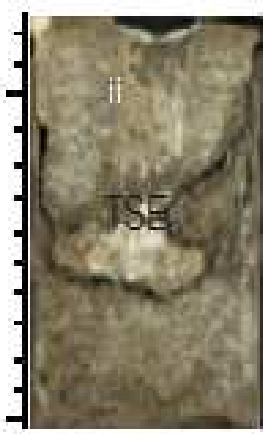

(b)

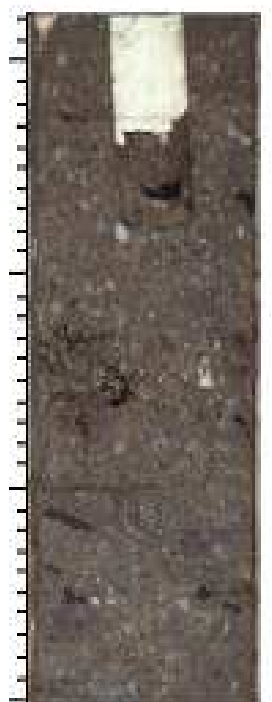

(c)

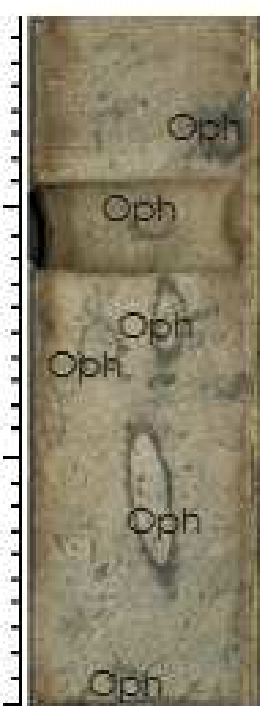

(d)

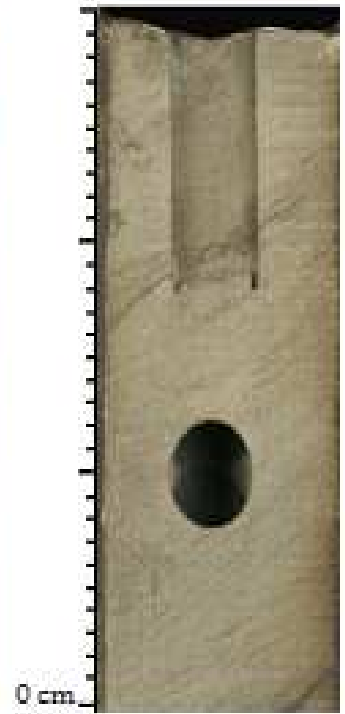

(e)

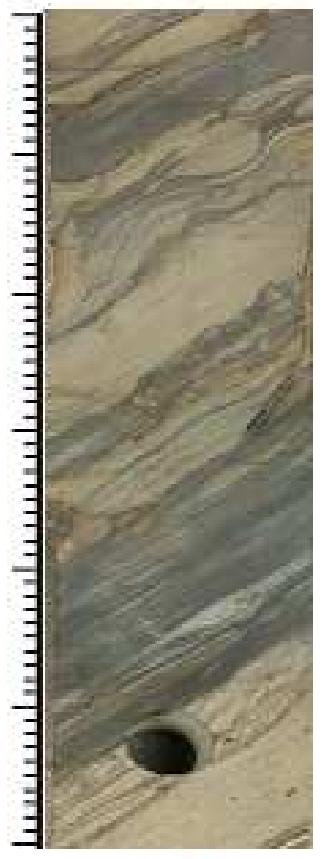

(g)

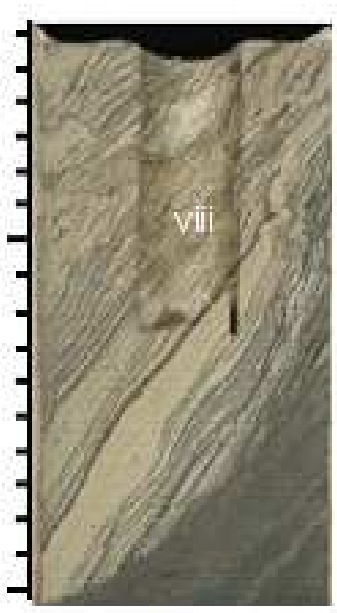

(h)

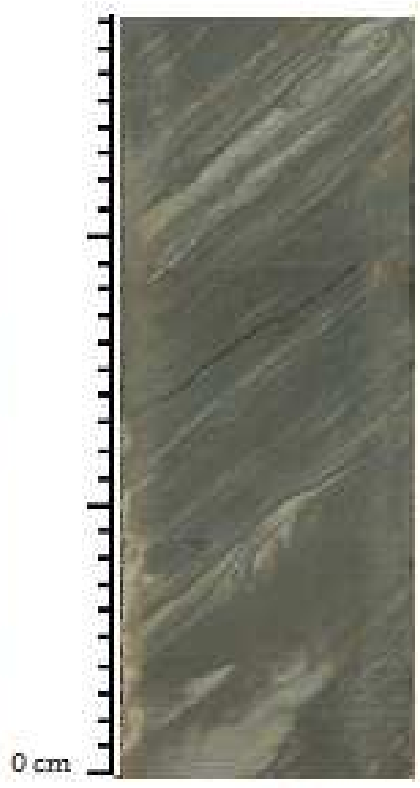

(i)

Fig. 3. (a to i): Core photos showing diagnostic features of lithofacies identified within the cored interval (Oph = Ophiomorpha, TSE $=$ transgressive surface of erosion)

\section{Litho Facies Associations (LFA)}

Five associations of the aforementioned and described lithofacies (Table 1) along with wireline log shapes led to the identification of depositional subenvironments shown in Fig. 4 and described as follows:

LFA 1: Transgressive Tidal flat. Dark grey coloured shale with intervals of mm-cm thick siltstone and ripple laminated clean fine-grained sandstone, bioturbated and shaly is interpreted to record deposition in a tidal flat. It is an open marine deposit that completes a transgressive phase (Fig. 4). The thin clean and sharp based upward fining sandstone interval is interpreted as flood tidal current washover sand. Abrupt deepening, sideritic concretions, flaser and lenticular beddings, truncation, washover sands and an increase of 
bioturbation indicate open marine tidal flat deposit in a retrogradational depositional system (Davis Jr. and Dalrymple, 2012).

LFA 2: Transgressive marine sandstone. Massive coarse-to fine-grained sandstone (lithofacies ii), approximately $0.6 \mathrm{~m}$ thick, carbonaceous and micaceous, underlain by basal lagged erosive surface and underlie LFA 1, is interpreted as transgressive marine sandstone (Fig. 4). The basal lag represents basal reworked deposit of the transgressive sea. Carbonaceous and micaceous contents are reflection of deposition in an environment less winnowed by waves and longshore current and also close to distributary channel and mouth bar deposition (Weber, 1971).

LFA 3: Proximal delta front-mouth bar. This lithofacies association start with cross-stratified fineto medium-grained sandstone (lithofacies v) and grades upward through range of lithofacies (lithofacies iv, iii and ii) to sandy conglomerate (Fig. 4). It is moderately to poorly sorted, exhibit coarsening upward trend and has high mica flakes content. Biogenic textural heterogeneity is attributed to abundant Ophiomorpha, rare Palaeophycus and Diplocraterion burrows. Very coarse grains, high mica content and poor sorted texture and sedimentary structures (massive, cross-bedding and rare hummocky laminations) indicate high energy condition typical of distributary channel. Abundant Ophiomorpha, Rare Palaeophycus and Diplocraterion burrows reflect deposited sediment in oxygenated, high energy and shallow water depositional setting (MacEachern et al., 2005; Pemberton et al., 2009). The inclination of strata implies delta slope progradation.

LFA 4: Distal delta front deposit. The association that grades upward from concave sharp based inclined inter-laminated sand and shale with convolute structures (lithofacies viii) through inclined heterolithic fine-grained sandstone and silty shale (lithofacies vii) and capped by mud draped high angle cross laminated sandstone (lithofacies vi) is interpreted as distal delta front or distal-mouth bar facies association (Fig. 4). From the mid part of the coarsening-upward successions to the top is characterised by high angle cross-laminations, small scale hummocky and swaley cross-laminations, wave ripple laminations or oscillation ripples, rare load structures, flaser bedding and 2-4 cm mud bed intercalations and sporadic or sparse bioturbation (BI $=1$ to 2 ) by rare Fugichnia (an escape burrow), rare synaeresis crack, localized sand filled Chondrites, rare Planolites and Palaeophycus burrows and stunted Phycosiphon, Cylindrichnus and Lockeia burrows.

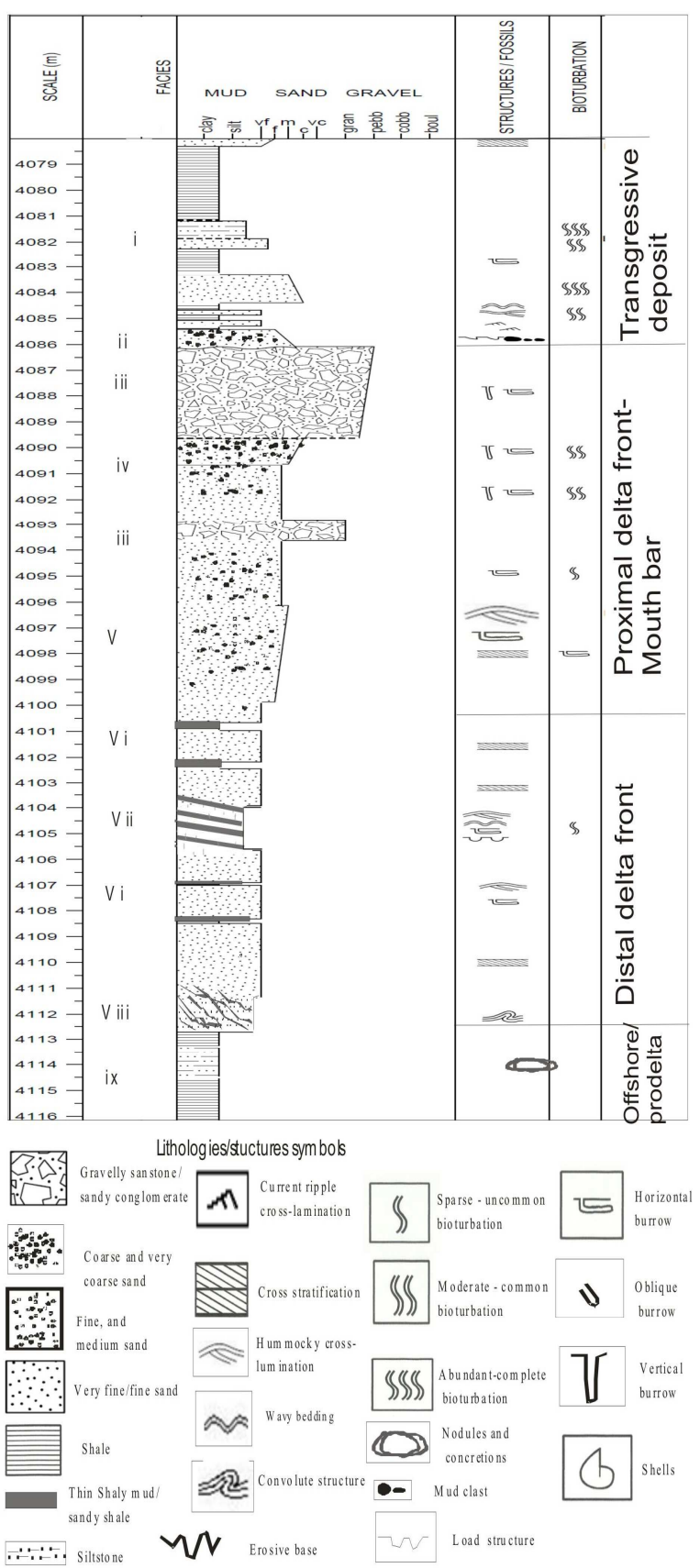

Fig. 4. Lithofacies log of D3 reservoir cored interval showing sedimentological heterogeneities of Delta front- mouth bar reservoir sands

The base of the succession is characterised by convoluted or contorted laminations with sparse to no traces of bioturbation. Sporadic or sparse bioturbation and stuntedness of some burrows indicate suppressed biogenic activities attributed to the stress in environment caused by fluctuating salinities or temperatures combined with a large suspended-sediment load and 
rapid deposition (MacEachern et al., 2005; 2012; Bhattacharya and MacEachern, 2009).

LFA 5: Offshore-Prodelta. A gradual coarseningupward succession made up of dark grey coloured massive shale, grading upward to lenticular-wavy but rarely contorted silty sandstone and shale couplets (lithofacies ix) and underlying the distal delta front facies successions described above is interpreted to represent offshore-prodelta transitional setting (Fig. $4)$. It is sparsely to unbioturbated ( $\mathrm{BI}=0-1)$ and the underlying massive shale is locally fractured and sideritic. According to Nwozor and Onuorah (2014), fractures are pore fluid escape structures as a result of high pressure caused by rapid sediment deposition. The locally sideritic massive shale with lack of biogenic textural heterogeneity by burrowing organism records deposition in an anoxic environment, below storm wave base, in offshore setting (MacEachern et al., 2005).

\section{Petrophysical Descriptions and Heterogeneity}

\section{Porosity-Permeability Relationship, Grain Density} Diversity and Permeability Heterogeneity

Permeability and porosity relationships/heterogeneity; and mineral grain density diversity were evaluated to understand D3 reservoir quality heterogeneity. According to Fitch et al. (2015), it is important to understand the variability or heterogeneity of petrophysical properties, so as to understand whether there is any pattern to the variability and appreciate the significance of simple averages used in geologic and simulation modelling.

The cross-plot of petrophysical data shown in Fig. $5 \mathrm{a}$ indicates that permeability values ranges up to six orders in magnitude, with broad range of porosity which indicates heterogeneity. The overlapping of data and low correlation coefficient could be attributed to the effect of disperse clay in the sandstone reservoir (Coskun et al., 1993). However, up to eighty percent of the data points have permeability values that range from 10.5 to $1000 \mathrm{md}$ which indicates moderate to excellent reservoir quality (Dresser, 1982).

Porosity histogram and cumulative frequency distribution shown in Fig. 5b indicate broad normal porosity distribution with values that range from 5.5 to $26.3 \%$. The distribution is negatively skewed (i.e., skewed to the left) and reflects grain size gradation. A normal distribution, is given by a homogeneous reservoir, while skewed broad distribution represents a heterogeneous reservoir zone (Hurst and Archer, 1986). Similarly, the histogram of permeability distribution
(Fig. 6a) shows broad distribution, large difference between arithmetic average and the geometric mean, reflecting the heterogeneous nature of a delta frontmouth bar reservoir deposit. It is also negatively skewed, with samples of low permeability values less than $30 \%$. Core permeability ranges from $\mathrm{O}$ to over $2000 \mathrm{md}$. Therefore, though the histograms of porosity and permeability indicate heterogeneity, the skewedness of the average core porosity (19.4\%) and permeability (2172 md) to higher values indicate high quality reservoir (Dresser, 1982).

Figure $6 \mathrm{~b}$ is the histogram and the cumulative frequency curve of mineral grain density distribution in the studied reservoir of well Gabi 55. The mineral grain density ranges from 2.63 to $2.78 \mathrm{~g} / \mathrm{cm}^{3}$. More than $40 \%$ of the samples analysed have grain density more than $2.7 \mathrm{~g} / \mathrm{cm}^{3}$ The histogram indicates a bimodal distribution (two peaks) with an overall mean of 2.71 $\mathrm{g} / \mathrm{cm}^{3}$ and median of $2.73 \mathrm{~g} / \mathrm{cm}^{3}$. The dominant mode is centred at $2.74 \mathrm{~g} / \mathrm{cm}^{3}$ and represents the grain density of mica group, while the secondary mode occurs in the grain density range, approximately 2.64 to $2.65 \mathrm{~g} / \mathrm{cm}^{3}$ (up to $40 \%$ of the samples analysed), representing quartz (Dewan, 1983). Other suspected minerals in the rock volume that contributes to the variability observed in the histogram are calcite $\left(2.71 \mathrm{~g} / \mathrm{cm}^{3}\right)$, plagioclase feldspar $\left(2.7 \mathrm{~g} / \mathrm{cm}^{3}\right)$ and clay $\left(2-2.9 \mathrm{~g} / \mathrm{cm}^{3}\right)$ such as illite, kaolinite and montmorillonites (Dewan, 1983; Schlumberger, 2009). Therefore, the most dominant framework grains in the studied reservoir sands are quartz and mica. This is in agreement with the identification of a lots of mica flakes in most of the lithofacies (Table 1) identified in the core samples description. The mineral grain density heterogeneity can be attributed to the sediment provenance, level of wave/tidal winnowing processes of the environment of deposition and the distance of sediment travel (Nichols, 2009; Dias et al., 1984).

Figure 7 shows the Permeability distribution and Dykstra-Parson Coefficient plot of D3 reservoir-a mouth bar deposit. The Dykstra-parson coefficient of variation $\left(V_{d p}\right)$ of 0.97 indicates that the reservoir deposit is highly heterogeneous with high intra sandbody compartmentalization potential. The different colour groupings or clusters represent different rock types which is approximately eight in number. The cluster with the highest number of data points has permeability that range from 2000 to $10,000 \mathrm{md}$, while only three clusters of few data points fall between 0.1 and $10 \mathrm{md}$. Therefore though, the deltafront reservoir sandstone is very heterogeneous, it is of very good to excellent quality (Dresser, 1982). 


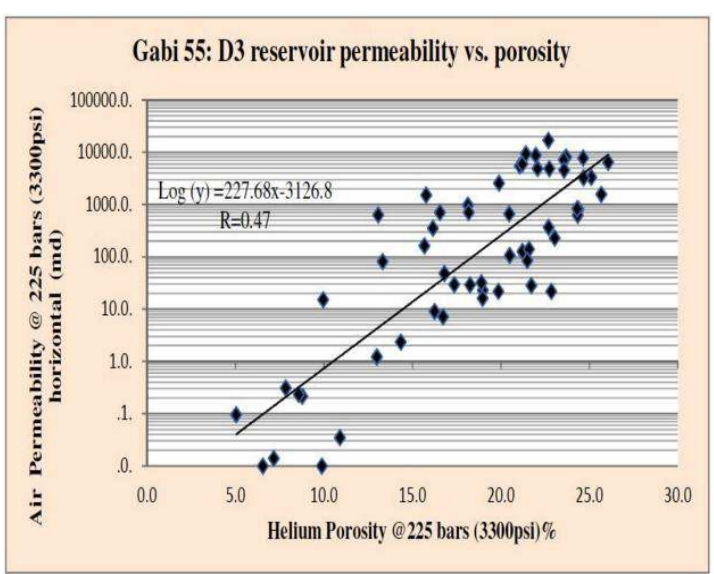

(a)

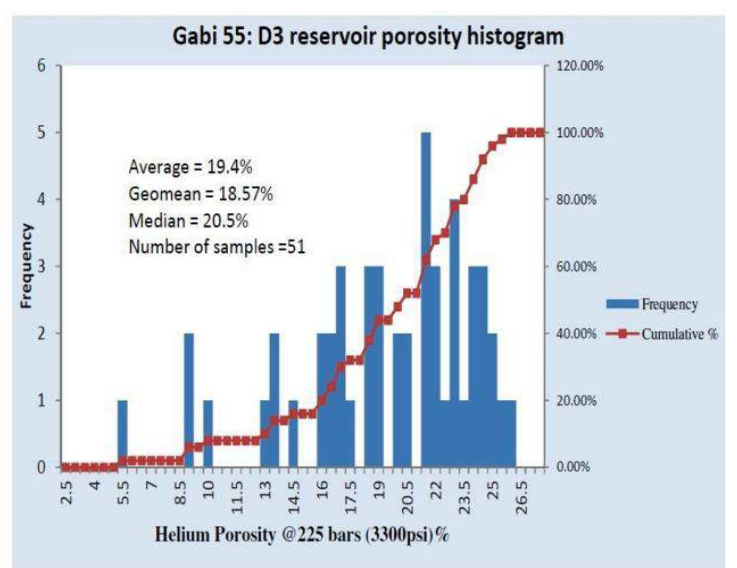

(b)

Fig. 5. (a) Shows cross plot of core permeability and porosity, giving visual clues to the presence of heterogeneities in the petrophysical data. (b) Porosity histogram of all lithofacies. It shows negative skew distribution of porosity values.

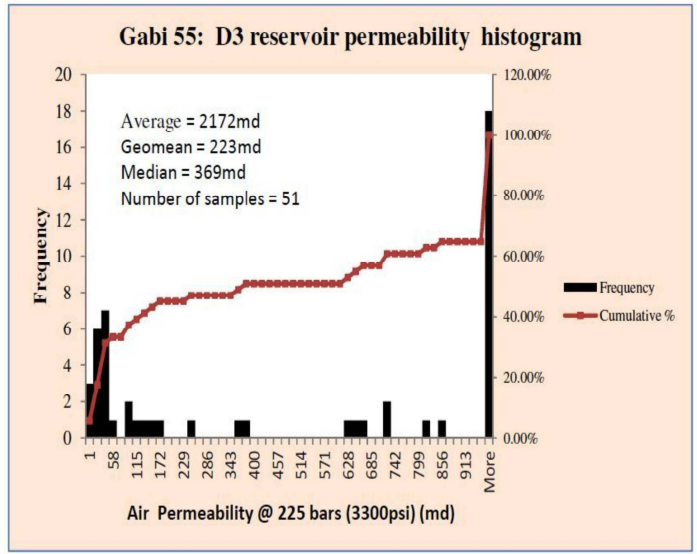

(a)

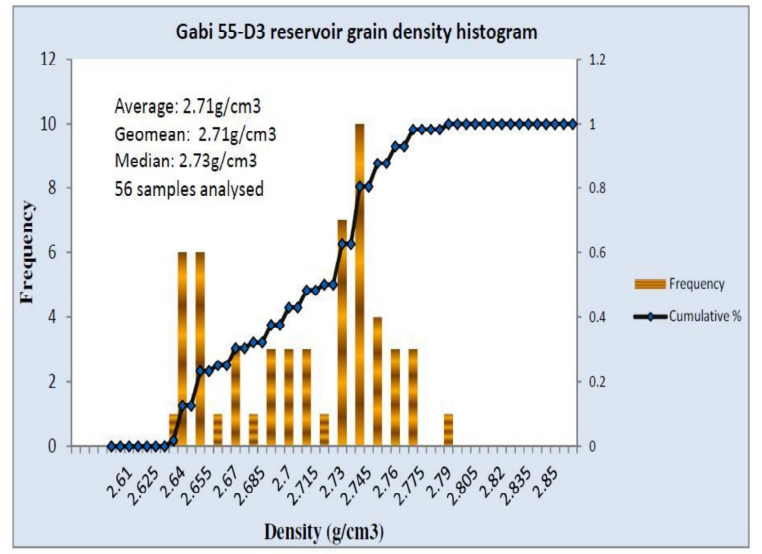

(b)

Fig. 6. (a) Permeability histograms of all lithofacies showing skewed broad distribution of core permeability values, (b) Grain density histogram showing diversity of minerals in the cored interval

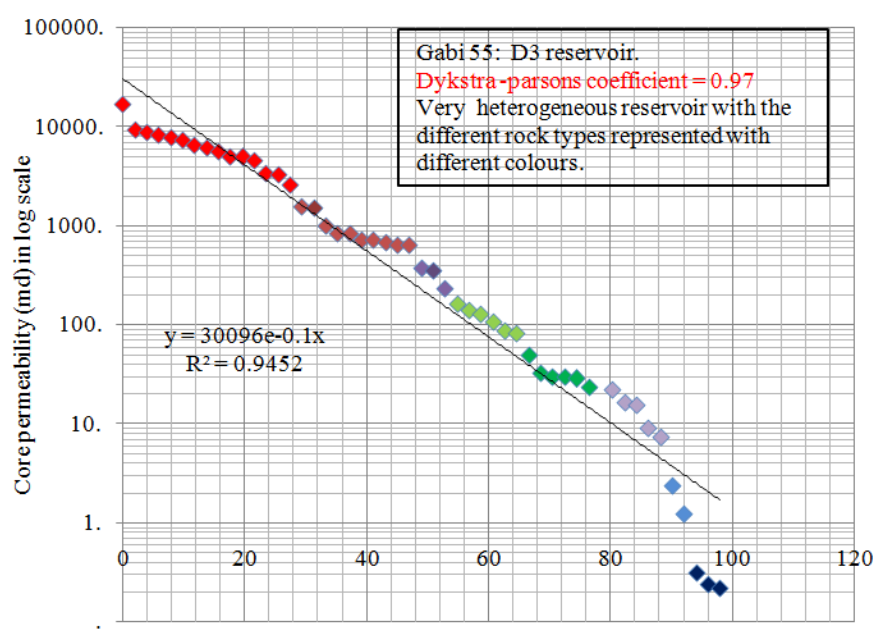

Probability of samples with permeability >

Fig. 7. Permeability distribution and Dykstra-Parson coefficient of core permeability variation. The coefficient of variation $\left(\mathrm{V}_{\mathrm{dp}}\right)$ of 0.97 indicates that the reservoir is vertically very heterogeneous 


\section{Classifications of D3 Reservoir Sands Pore- Throats Sizes}

Winland R35 values calculated with Equation 2 was classified into various rock pore types using semi-log plot as shown in Fig. 8a. The pore types identified include mega porous rock type $(>10 \mu \mathrm{m})$, macroporous rock type (between 2.0 and $10 \mu \mathrm{m}$ ), mesoporous rock type (between 2 and $0.5 \mu \mathrm{m}$ ), micro-porous rock type (between 0.2 and $0.5 \mu \mathrm{m}$ ) and nanoporous rock type $(<0.2 \mu \mathrm{m})$ rock types (after Boada et al., 2001). The result shows that the greater percentage of the rock volume is made of macro-porous to megaporous rocks. Shales and silty/sandy shales within the cored interval are nanoporous to microporous and hence considered as flow barriers.

Figure $8 \mathrm{~b}$ illustrates the pore-throat sorting and distribution. The histogram indicates broad distribution and heterogeneity that can be attributed to different grain sizes, sorting and the presence of detrital clays. The average pore-throat size of 22.75 $\mu \mathrm{m}$ suggest high quality reservoir, with well-sorted and connected pores.

Classification of Hydraulic Flow Units (HFU) From Flow Zone Indicators (FZI)

Graphical clustering using classical RQI- $\varnothing_{z}$ plot was used to group Flow Zone Indicators (FZI) values calculated with Equation 3-5, into Hydraulic Flow Units (HFU) as shown in Fig. 9a. Nine different clusters of data represented with parallel lines, with each line of data set having similar Flow Zone Indicators (FZI) were identified (Amaefule et al., 1993; Svirsky et al., 2004). The clusters are the Hydraulic Flow Units (HFU1 to 9) which control the flow of fluid within D3 reservoir sand-body. The quality of reservoir increased from HFU 9 with an average flow zone indicator of $0.016 \mu \mathrm{m}$ to HFU1 with an average flow zone indicator of $2.68 \mu \mathrm{m}$. HFU 8 and 9 are considered as fluid flow barriers corresponding to the micro-porous and nano-porous rocks identified with Winland method respectively.

The cross-plot of $\mathrm{r} 35$ and flow zone indicator values (Fig. 9b) indicates a very high correlation with regression coefficient of 0.98 . This suggest that both Winland r35 and Flow zone indicator method gives good definition of flow capacities of reservoir units and any of the two methods can be used for rock typing (Rushing et al., 2008).

\section{Depositional Control on Flow Units Distribution}

Table 2 presents the Average petrophysical properties for each Hydraulic Flow Units (HFU) in D3 reservoir sand-body and depositional sub- environments. From Table 2, it can be observed that the petrophysical properties of D3 reservoir sand-body are controlled by depositional processes characterised by variable sorting and clay deposition. This is underscored by the fact that the highest quality reservoir unit, HFU 1, is not at the crest of the coarsening upward delta front-mouth bar deposit made up of the largest grain sizes (sandy conglomerates/gravelly sandstone) but that of massive and Ophiomorpha burrowed, well sorted fine- to coarse- grained sandstone (Table 1).

Though the Hydraulic Flow Units (HFU) are related to geological facies, but they do not coincide with boundaries. Within a single depositional facies or sub-environments of deposition, you have a number of hydraulic flow units and also a single lithofacies can be characterised by a range of hydraulic flow units. For example as shown in Table 2, HFU 2 is found in massive well sorted medium-to coarse-grained sandstone of transgressive tidal flat and proximal delta front-mouth bar deposition, which is an evidence of heterogeneity as pore-throat geometrical characteristics are shared among lithofacies.

Prediction of Petrophysical Properties of D3 Reservoir Interval in a well with no Core Measurement Data using Multiple Regression Analysis

Predictive mathematical models developed with multiple regression analysis were used to predict permeability, pore-throats (r35) and flow zone indicator values of D3 reservoir in well Gabi 56, with no core measurement data (Fig. 1). The summary of multiple regression statistics and the predictive mathematical models of the three petrophysical parameters-permeability $(\mathrm{k})$, pore throat radius (r35) and Flow Zone Indicator (FZI) are shown in Table 3. The Regression coefficient (R) gives the relationship between the dependent and the independent variables. While coefficient of determination $\left(\mathrm{R}^{2}\right)$ gives the proportion of percentage of the variance in the dependent variable that is explained by the model. The $\mathrm{F}$ and significant $\mathrm{F}$ values are from the Analysis of Variance (ANOVA) and they indicate the statistical significance of the models.

As shown in Table 3 , the multiple (variable) regression coefficients (R) of the three mathematical models are high and they all indicate good relationship between the dependent and independent variables (Mohaghegh et al., 1997; Wendt et al., 1986). The significance $\mathrm{F}$ values of the three models are less than 0.0005 which indicates that they are statistically significance. However, the permeability predictive mathematical model has the 
highest multiple regression coefficient $(\mathrm{R})$ and followed by that of R35, which implies them as the best predictive

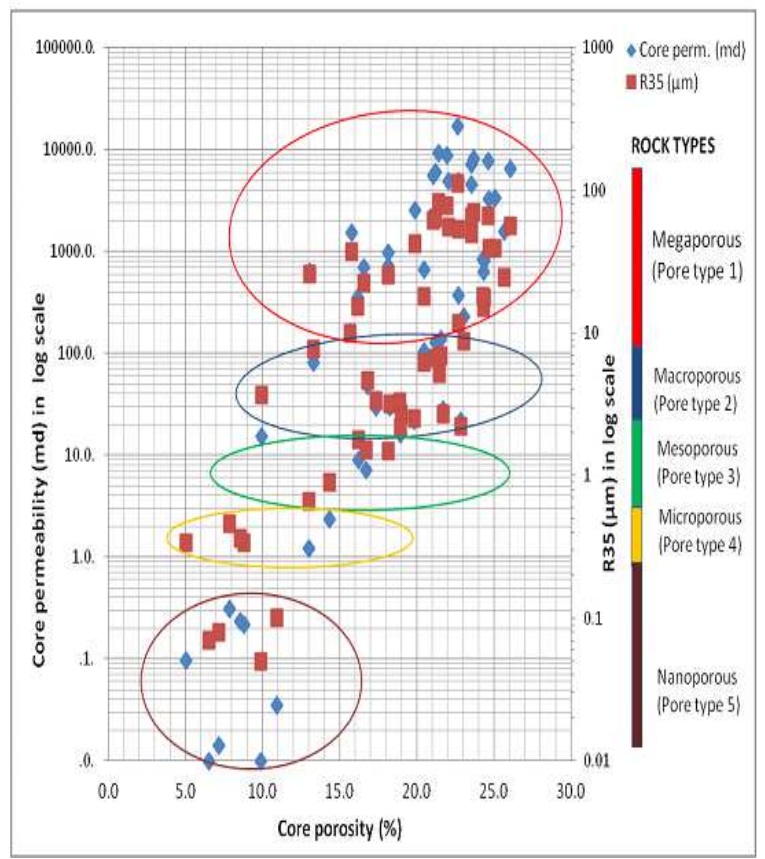

(a) models and their predicted values most reliable for reservoir flow units layering and correlation.

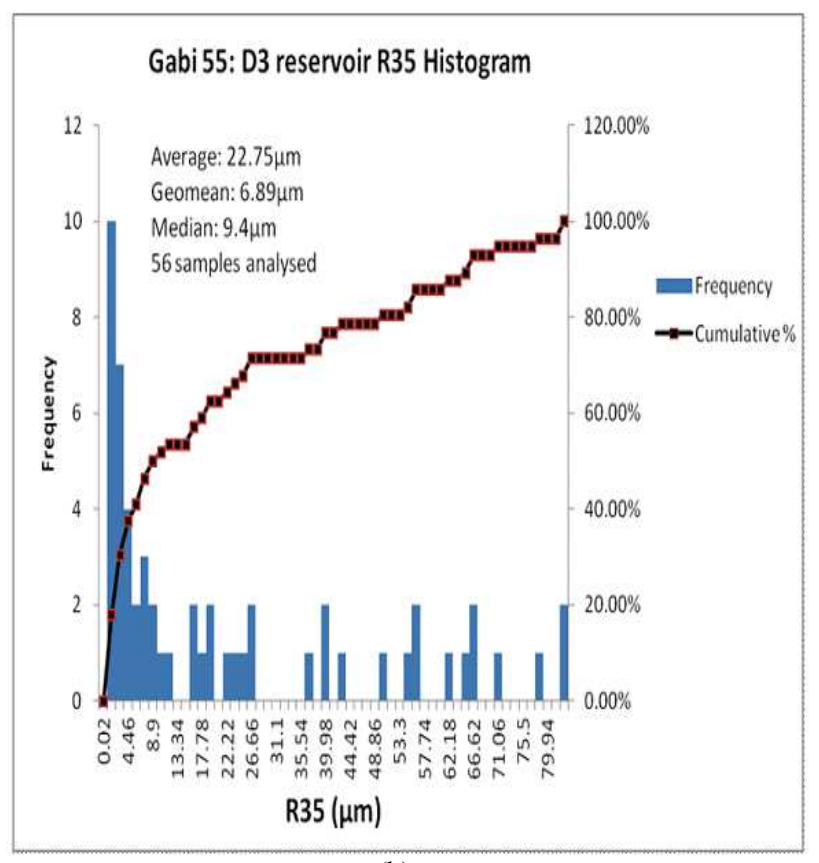

(b)

Fig. 8 (a) Winland semi-log plot showing various pore types. (b) Histogram and cumulative frequency distribution of R35

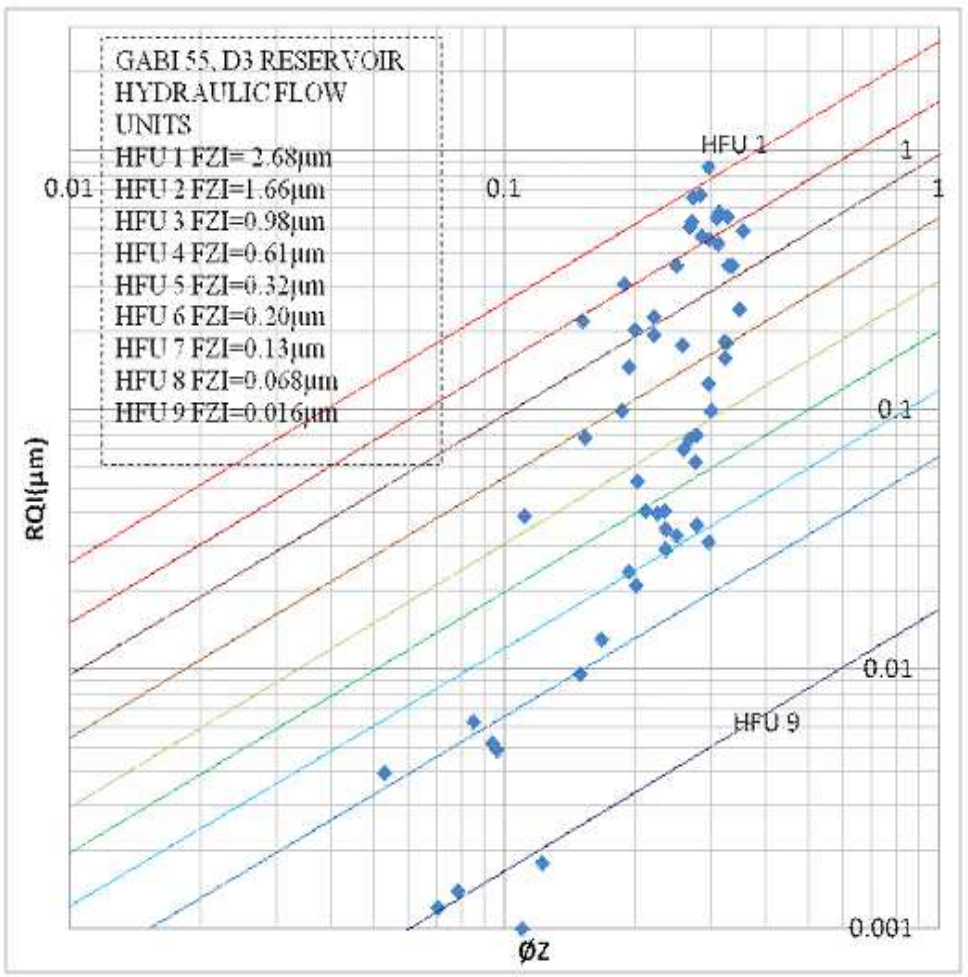

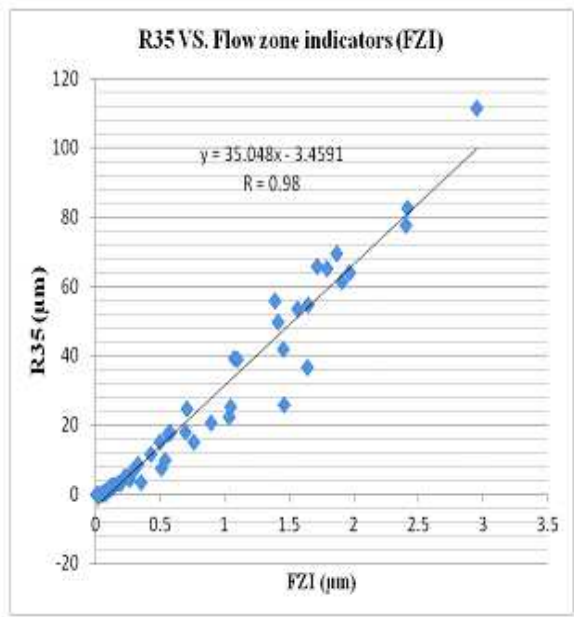

(b)

Fig. 9. (a) Plot of RQI vs ØZ and Hydraulic Flow Units (HFU) from the averaged Flow Zone Indicators (FZI) through graphical groupings. (b) Cross plot of R35 values and flow zone indicators 
Table 2. Average petrophysical properties for each Hydraulic Flow Units (HFU) in D3 Reservoir and depositional environments

\begin{tabular}{|c|c|c|c|c|c|}
\hline HFU & Mean FZI $(\mu \mathrm{m})$ & Mean core $K(\mathrm{md})$ & Mean core $\varnothing(\%)$ & Lithofacies & Sub-environments of deposition \\
\hline 1 & 2.68 & $11,706.67$ & 21.9 & $\begin{array}{l}\text { Ophiomorpha burrowed and } \\
\text { cross-stratified well sorted fine- } \\
\text { to coarse-grained sandstone }\end{array}$ & Proximal delta front-mouth bar \\
\hline 2 & 1.660 & $4,756.08$ & 9.87 & $\begin{array}{l}\text { Massive fine- to coarse-grained } \\
\text { sandstone }\end{array}$ & $\begin{array}{l}\text { Transgressive sandstone and } \\
\text { proximal delta front }\end{array}$ \\
\hline 3 & 0.980 & $2,420.00$ & 20.74 & $\begin{array}{l}\text { Massive well sorted fine- } \\
\text { to coarse-grained sandstone }\end{array}$ & $\begin{array}{l}\text { Tidal washover sands and } \\
\text { proximal delta front deposits }\end{array}$ \\
\hline 4 & 0.610 & 639.73 & 20.55 & Sandy conglomerates & $\begin{array}{l}\text { Crest of proximal delta } \\
\text { front-mouth bar }\end{array}$ \\
\hline 5 & 0.320 & 175.84 & 19.70 & $\begin{array}{l}\text { Mud draped high angle } \\
\text { cross-laminated sandstone }\end{array}$ & Distal delta fronts \\
\hline 6 & 0.200 & 59.68 & 18.90 & $\begin{array}{l}\text { Heterolithic very fine-grained } \\
\text { sandstone and shale }\end{array}$ & $\begin{array}{l}\text { Distal delta fronts and } \\
\text { transgressive tidal flat }\end{array}$ \\
\hline 7 & 0.130 & 19.96 & 19.28 & $\begin{array}{l}\text { Heterolithic very fine-grained } \\
\text { sandstone, silty shale and shale }\end{array}$ & $\begin{array}{l}\text { Distal delta fronts and } \\
\text { transgressive tidal flat }\end{array}$ \\
\hline 8 & 0.068 & 0.74 & 9.58 & Interbedded siltstone & $\begin{array}{l}\text { Prodelta and transgresive } \\
\text { tidal flat }\end{array}$ \\
\hline 9 & 0.016 & 0.01 & 8.60 & Massive shale & $\begin{array}{l}\text { Offshore and transgresive } \\
\text { tidal flat }\end{array}$ \\
\hline
\end{tabular}

Table 3. Summary of multiple regression statistics and predictive mathematical models of D3 reservoir

\begin{tabular}{llllll}
\hline Predicted parameter & Multiple R & R square & F & Sig. F & Predictive model \\
\hline K (md) & 0.82448 & 0.68 & 56.25 & $<0.00005$ & $\left.\log (\mathrm{K})=13.54154-0.034126^{*} \gamma-4.08590^{*} \rho_{\mathrm{b}}\right)$ \\
R35 & 0.82178 & 0.675 & 55.12 & $<0.00005$ & $\log (\mathrm{R} 35)=5.95796-0.01928 * \gamma-1.69969 * \rho_{\mathrm{b}}$ \\
FZI & 0.6662 & 0.54 & 21.15 & $<0.00005$ & FZI $=2.4487-0.0168 * \gamma-0.2832^{*} \rho_{\mathrm{b}}$ \\
\hline
\end{tabular}

$\gamma=$ Gamma ray $\log$ value. $\rho_{\mathrm{b}}=$ bulk density $\log$ value. $\mathrm{K}=$ Permeability

In the application of the mathematical models, the shortcomings of using multiple regression analysis in the model development and properties' predictions, expressed by Mohaghegh et al. (1997), such as prediction of negative values were taken into considerations. For example, negative values were predicted with gamma ray log values greater than 50Api, for sandy shale-shale. Therefore, all predicted negative values were taken as that of nanoporousmicroporous rock intervals (r35 less than $0.4 \mu \mathrm{m}$ ) that are fluid flow barriers.

\section{Intra Sand-Body Compartmentalization}

Vertical and lateral intra sand-body compartmentalization in D3 reservoir was further evaluated by plotting the average flow zone indicator, permeability and r35 values against depth. The rock type identified as fluid flow barriers were used to divide the studied sand-body into five faciescontrolled flow unit sets or compartments as shown in Fig. 10. The vertical flow barriers are vertical intercalated sandy shales and shales. Compartments 2,
3 and 4, correlate between two close-spaced wells, while compartment 5 pinches out down-dip due to the interfingering of distal delta front deposit with prodelta shale. Compartment 1 which is tidal inlet reservoir compartment also pinches out down-dip.

The lateral correlation of three major thick compartments between the two wells indicates lateral intra sand-body continuity. This finding is in agreement with Keyu et al. (2004) that wave dominated delta front reservoirs such as that of shoreface and mouth bars have excellent lateral continuity, but on the contrary, vertical connectivity is found here to be poor to moderate due to intercalated shales and mud drapes. Comparing delta front-mouth bar sands described here to that of shoreface described by Oyanyan and Oti (2015b), in a mixed-processes delta, mouth bar sands in is found to be more heterogeneous and also more vertically compartmentalized than shoreface sands which are actually mouth bar sands that have been winnowed by waves and tide and distributed along shoreline by longshore current (Nichols, 2009). 


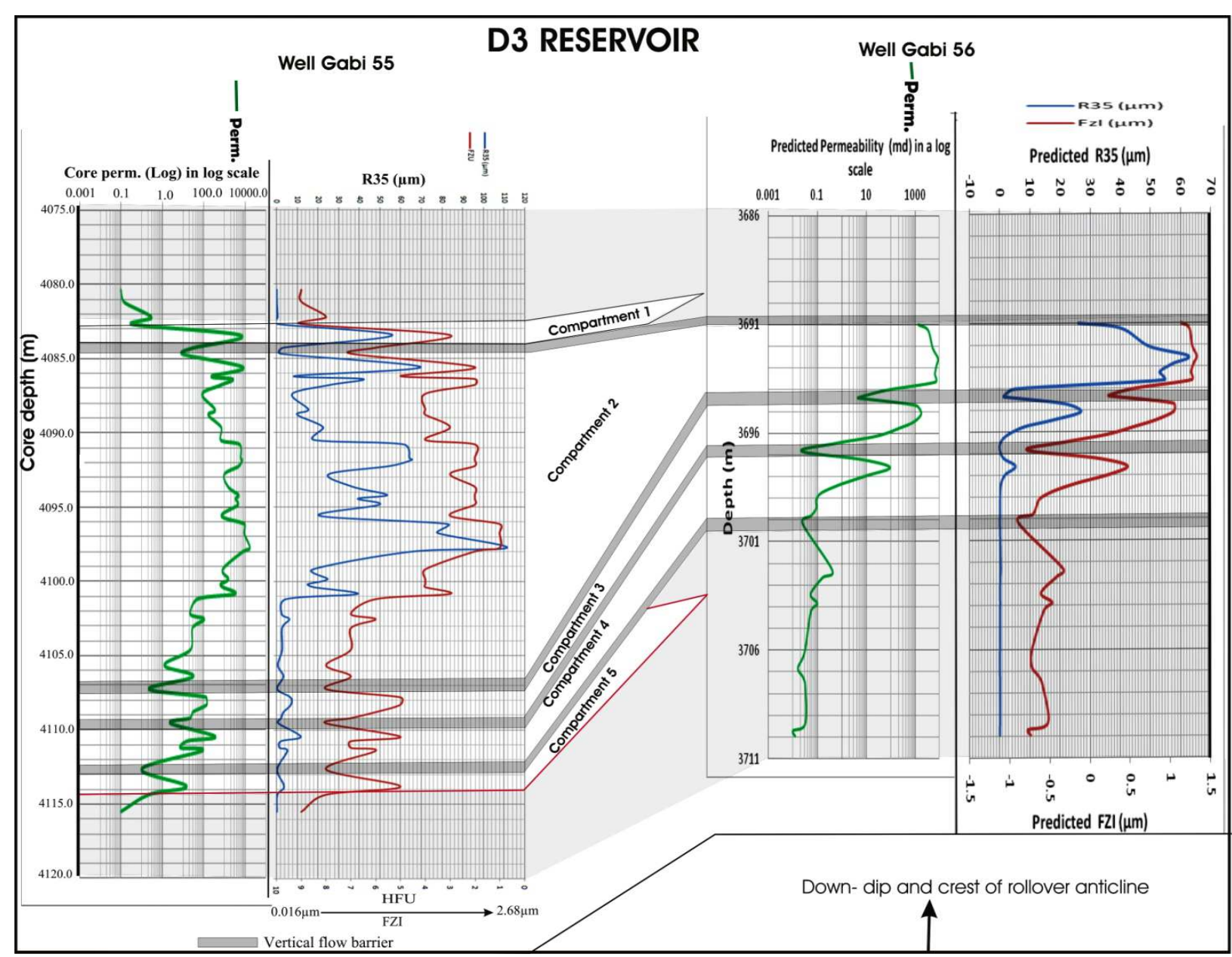

Fig. 10. Intra sand-body compartmentalization scheme of D3 reservoir sand-body showing vertical layering that can be used as a guide for adequate well completion

\section{Pressure Data Analysis, Fluid Typing and Confirmation of Intra Sand-Body Compartmentalization}

Figure 11 shows the D3 reservoir pressure-depth profile (gradients) and fluid types based on fluid densities. The following characteristics can be observed from the pressure-depth profile:

Most of the formation pressure samples are greater than $400 \mathrm{psi}$ which indicates over-pressured zones (Opara, 2011).

Four compartments are recognised. Compartments 1,3 and 4 are characterised by pressure reversal or regression which can be attributed to pressure breach by fault or fractures (Shaker, 2012; 2014), while compartment 2 is the only laterally drained normal pressured reservoir compartment. Fractures in seals (shale) occur when then the reservoir pore pressures exceed the confining pressure in seal (shale) (Shaker, 2012).
Compartments 1 to 3 are equivalent to compartments 1 to 3 identified with r35, flow zone indicators and core permeability depth profile (Fig. 11). It appears that compartment 4 replaces compartments 4 and 5 identified with $\mathrm{r} 35$, flow zone indicators and core permeability depth profile (Fig. 10). The confirmation of one compartment with pressure data in place of two compartments is an indication of seal failure by fractures and communication pathway through it (Shaker, 2012; 2014; Nwozor and Onuorah, 2014; O'connor et al., 2013). Note that fractures were identified in lithofacies "ix" (Table 1). The fractures caused decrease in formation pressure from $4668.05 \mathrm{psi}$ at $4103 \mathrm{~m}$ to $4624.23 \mathrm{psi}$ at $4103.9 \mathrm{~m}$ from which it further increases with depth. The pressure breach possibly led to the formation of gas condensate which is then suspected to be a retrograde condensate (Fan et al., 2005/2006). 


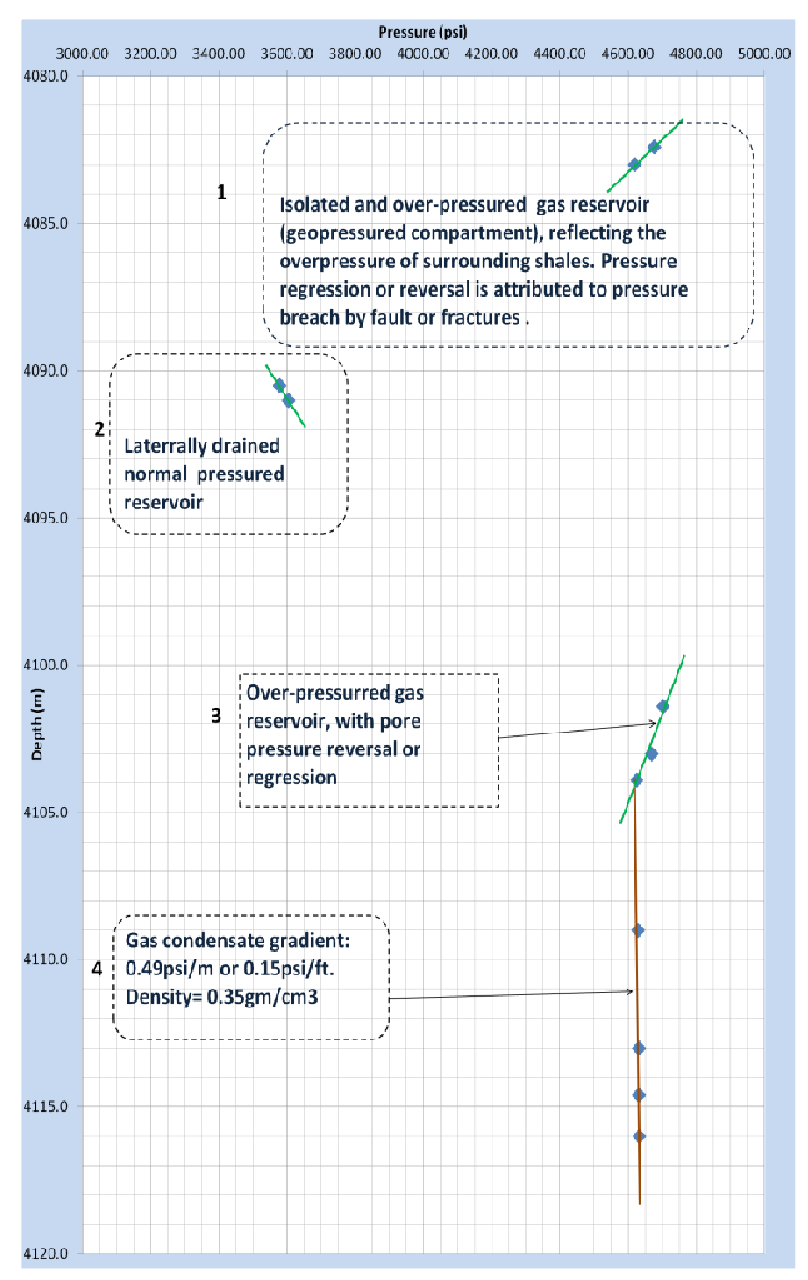

Fig. 11. Pressure-depth plot showing fluid types and isolated pressured compartments

Therefore, based on this finding, fractures in an over pressured depth zones reduce vertical subsurface fluid compartmentalization in a hydrocarbon bearing heterolithic deposit of distal delta front. However, reduction in pressure due to production can result in dynamic compartmentalization and consequently, reduction in hydrocarbon recovery (Aguilera, 2003).

\section{Discussion}

Core samples descriptions, statistical analysis of petrophysical data, flow units determination and distribution and vertical reservoir layering has given a better understanding of the quality of delta front-mouth bar reservoir and the distribution of its petrophysical components. This can help in the optimization of well bore placement during field development or well recompletion to produce hitherto bypassed oil pool.

The number of lithofacies, Dystra-parson's coefficients and the number of hydraulic rock types showed that the studied delta front-mouth bar reservoir sands is very heterogeneous and the quality of reservoir is depositionally controlled. Also, the crossplot of r35 and flow zone indicator values indicates strong relationship between permeability and porethroat (Ma and Morrow, 1996). The average core porosity and permeability values of $20.5 \%$ and $2,172 \mathrm{md}$ respectively, as well as the intervals with core porosity $(22.5-29.5 \%)$ and core permeability $(7560-27320 \mathrm{md})$ values anomalously higher than the stated average values and the dominance of mesoporous (between 0.5 and 2.0 $\mu \mathrm{m})$ to megaporous rock types $(>10.0 \mu \mathrm{m})$ from semi$\log$ plot classification of Winland r35 values indicate that the studied sand-body forms very good to excellent reservoir quality (Svirsky et al., 2004; Dresser, 1982). Such a reservoir quality at depth that range from 3323 to $4120 \mathrm{~m}$ suggest that the usual diagenetic processes responsible for permeability and porosity reduction (e.g., compaction, cementation and pressure solution), though might be active for a long time, failed to diminished the quality of the reservoir (Hayes, 1979; Coskun et al., 1993). Bloch et al. (2002) adduced some factors that could have preserved the porosity and permeability values which include: (1) Sandstone richness in rigidgrains (i.e., quartz grains). Rigid-grain rich sandstone compact less than ductile-grain (clay and rock fragment) rich sandstone. Grain density and mineral diversity analysis indicate the dominance of quartz (average of $2.65 \mathrm{gm} / \mathrm{cc}$ ). (2) Fluid overpressures, typical of Niger Delta basin caused by compaction disequilibrium associated with rapid burial. According to Nwozor and Onuorah (2014), fluid pressures retard compaction process resulting in reduction in the grain contact stress in Niger Delta reservoir sandstone. (3) Aquathermal expansion. (4) Early hydrocarbon emplacement. Also according to Bloch et al. (2002), lower thermal gradients that are normally associated with the rapid burial minimized loss of porosity by quartz cementation through overgrowth. Otherwise, the abundant mica flakes in the studied delta front-mouth bar deposit suppose to act as catalyst for chemical compaction and concomitant release of silica for quartz cementation at grain contact and consequently diminished the quality of reservoir. Therefore, though it was not possible to undertake petrographic studies of effect of diagenesis on the reservoir quality in the studied field, the positive relationship between porosity and permeability, the dominance of mesoporous to megaporous rock types and some reservoir intervals with anomalous porositypermeability values higher than average values, suggest very low potential for diagenetic reservoir compartmentalization.

Formation pressure data analysis validated the presence of vertical intra sand-body compartmentalization to a great extent. Five static 
vertical compartments were identified with r35 and core permeability values and hydraulic flow units' correlation between two wells but with only four validated with pressure data. The pressure data within the range of 4106.68-7197.20 psi indicate an overpressured reservoir (Opara, 2011; Nwozor and Onuorah, 2014). The Pressure-Depth (P-D) plot is made up of two pressure regression intervals, indicating pressure breaches by fractures and two transgression intervals indicating laterally normal drained pressured reservoir (Shaker, 2012; 2014). The pressure breach by fractures was interpreted to have reduced the number of static compartments to four. This interpretation is consistent with the findings of O'Connor et al., (2013), who in their regional pressure studies in Niger Delta gave estimates of seal for highly pressured reservoir traps and also underscored the potential for seal breaching and dry wells in over-pressured reservoirs.

Stratigraphic factors that affect production are reservoir continuity, connectivity and the spatial distribution of permeability (Hovadik and Larue, 2007). Correlation of compartments and petrophysical properties between the two wells that are $0.8 \mathrm{~km}$ distance apart, made possible by the prediction of petrophysical properties of uncored reservoir intervals using predictive mathematical models developed with multiple regression analysis, indicates good reservoir connectivity/continuity. However, the combination of vertical intercalated shales, down-dip permeability pinch-out and possibly, up-dip juxtaposition of reservoir sands against shales by growth fault is believed to cause intra-reservoir compartmentalization within the studied sand-body (Ainsworth, 2010; Jolley et al., 2010; Yielding et al., 1997).

\section{Conclusion}

Core sample description and petrophysical data interpretations show that the studied delta front-mouth bar reservoir is highly heterogeneous. The heterogeneities in petrophysical properties are depositionally controlled with intercalated shales, mud drapes and grain size variations as main factors of reservoir heterogeneities as reflected in the numbers of lithofacies and hydraulic rock types.

The combination of core permeability, Winland r35 and flow zone indicators was adequately used for the vertical layering of the studied reservoir sand-body into flow units and flow barriers that are connected between two wells. Therefore, though the cored sand-body is heterogeneous, it demonstrates high lateral reservoir connectivity/continuity but with high potential for vertical sub-surface fluid compartmentalization.

Generally, intra-reservoir compartmentalization within the studied cored sand-body can be attributed to the combination of permeability down-dip pinch out, vertical intercalated shales and possibly, up-dip juxtaposition of reservoir sands against shales by growth fault. It is however, mainly stratigraphic as demonstrated by the variation of fluid pressure properties across laterally continuous shale layers.

Fractures in over-pressured zones were found to have reduced vertical reservoir fluid compartmentalization by intercalated shales. However, reduction in pressure due to hydrocarbon production can result in dynamic compartmentalization and consequently, reduced hydrocarbon recovery.

\section{Acknowledgment}

This paper is part of the $\mathrm{PhD}$ thesis submitted to the Department of Geology, University of Port Harcourt, Nigeria by the first author. The study was supervised by the second author. Special thanks to the lecturers and Graduate studies committee of the department for their support. Thanks also go to the Department of Petroleum Resources (DPR), Ministry of Petroleum of the Federal Republic of Nigeria and Total Exploration and Production Company Limited, Port Harcourt, Nigeria for the provision of the data used for this study.

\section{Author's Contributions}

Raphael Oaikhena Oyanyan: Carried out the $\mathrm{PhD}$ research from which this paper was written.

Michael Ndubuisi Oti: Supervised and coordinated the research.

\section{Ethics}

This article is original and contains unpublished material. The corresponding author confirms that all of the other authors have read and approved the manuscript and no ethical issues involved.

\section{References}

Aguilera, R., 2003. Geologic and engineering aspects of naturally fractured reservoirs. CSEG Recorder, 28: 45-49.

Ainsworth, R.B., 2010. Prediction of stratigraphic compartmentalization in marginal marine reservoirs. Geol. Society, London, Special Public., 347: 199-218. DOI: 10.1144/SP347.12

Amaefule, J.O., M. Altunbay, J. Tiab, D.G. Kersey and D.K. Keelan, 1993. Enhanced reservoir description: Using core and log data to identify hydraulic (Flow) units and predict permeability in uncored intervals/wells. Proceedings of the 68th Annual Technical Conference and Exhibition, Oct. 3-6, Houston, Texas, pp: 16-16. 
Bhattacharya, J.P. and J.A. MacEachern, 2009. Hyperpycnal rivers and prodeltaic shelves in the Cretaceous Seaway of North America. J. Sed. Res., 79: 184-209. DOI: 10.2110/jsr.2009.026

Bloch, S., R.H. Lander and L. Bonnell, 2002. Anomalously high porosity and permeability in deeply buried sandstone reservoirs: Origin and predictability. AAPG Bull., 86: 301-328. DOI: 10.1306/61EEDABC-173E11D7-8645000102C1865D

Boada, E., R. Barbato, J.C. Porras and A. Quaglia, 2001. Rock typing: Key approach for maximizing use of old well log data in mature fields, Santa Rosa field, case study. Proceedings of the Latin American and Caribbean petroleum Engineering Conference, Mar. 25-29, Buenos Aires, Argentina, pp: 7-7. DOI: $10.2118 / 69459-M S$

Coskun, S.B., N.C. Wardlaw and B. Haverslew, 1993. Effects of composition, texture and diagenesis on porosity, permeability and oil recovery in a sandstone reservoir. J. Petroleum Sci. Eng., 8: 279-92. DOI: $10.1016 / 0920-4105(93) 90005-Y$

Davis Jr, R.A. and R.W. Dalrymple, 2012. Principles of Tidal Sedimentology. 1st Edn., Springer Netherlands, ISBN-10: 9400701241, pp: 621.

Dewan, J.T., 1983. Essentials of Modern Open-hole Log Interpretation. 1st Edn., PennWell Books, Tulsa, ISBN-10: 0878142339, pp: 361.

Dias, J.M.A., O.H. Pilkey and V.M. Heilweil, 1984. Detrital mica: Environmental significance III north Portugal Continental shelf sediments. Comun. Serv. Geol. Portugal, 70: 93-101.

Doust, H. and E.M. Omatsola, 1990. Niger Delta. In: Divergent-Passive Margin Basins, Edwards, J.D. and P.A. Santogrossi (Eds.), American Association of Petroleum Geologists, Tulsa, ISBN-10: 0891813268, pp: 201-238.

Draper, N.R. and H. Smith, 1998. Applied Regression Analysis. 3rd Edn., Wiley and Sons, New York, ISBN-10: 0471170828, pp: 706.

Dresser, A., 1982. Well Logging and Interpretation Techniques: The Course for Home Study. 2nd Edn., Dresser Atlas, pp: 492.

Dykstra, H. and R.L. Parsons, 1950. The Prediction of Oil Recovery by Waterflood. In: Secondary Recovery of Oil in the United States, API and DP, American Petroleum Institute, New York, pp: 160-174.

Fan, L., B.W. Harris, A. Jamaluddin, J. Kamath and R. Mott et al., 2005/2006. Understanding gascondensate reservoirs. Oilfield Review.

Fitch, P.J.R., M.A. Lovell, S.J. Davies, T. Pritchard and P.K. Harvey, 2015. An integrated and quantitative approach to petrophysical heterogeneity. Marine Petroleum Geol., 63: 82-96.

DOI: $10.1016 /$ j.marpetgeo.2015.02.014
Fox, R.J. and M.B.J. Bowman, 2010. The Challenges and Impact of Compartmentalization in Reservoir Appraisal and Development. In: Reservoir Compartmentalization. Jolley, S.J., Q.J. Fisher, R.B. Ainsworth, P.J. Vrolijk and S. Delisle (Eds.), Geological Society of London, London, ISBN-10: 1862393168, pp: 247-247.

Hayes, J.B., 1979. Sandstone diagenesis-the whole truth. SEPM Special Public., 26: 127-139. DOI: $10.2110 /$ pec.79.26.0127

Hovadik, J.M. and D.K. Larue, 2007. Static characterizations of reservoirs: Refining the concepts of connectivity and continuity. Petroleum Geosci., 13: 195-211. DOI: 10.1144/1354-079305-697

Howell, J.A., A. Skorstad, A. MacDonald, A. Fordham and S. Flint et al., 2008. Sedimentological parameterization of shallow-marine reservoirs. Petroleum Geosci., 14: 17-34. DOI: $10.1144 / 1354-079307-787$

Hurst, A. and J.S. Archer, 1986. Sandstone reservoir description; an overview of the role of geology and mineralogy. Clay Minerals, 21: 791-809.

Jensen, J.J., L.W. Lake, P.W.M. Corbett and D.J. Goggin, 2000. Statistics for Petroleum Engineers and Geoscientists. In: Handbook of Petroleum Exploration and Production, Amsterdam, B.V. (Ed.), Elseview Science, pp: 338-338.

Jolley, S.J., Q.J. Fisher, R.B. Ainsworth, P.J. Vrolijk and S. Delisle, 2010. Reservoir Compartmentalization. 1st Edn., Geological Society of London, London, ISBN-10: 1862393168, pp: 362.

Keyu, L., B. Topham, L. Paterson, P. Eadington and P. Xiongqi, 2004. Sedimentary facies controls on the upscaling of petrophysical properties from core to $\log$ scales and its implications to petroleum exploration. Petroleum Sci., 1: 8-18.

Kolodzie, S.J., 1980. Analysis of pore throat size and use of the Waxman-Smits equation to determine OOIP in spindle field, Colorado. Proceedings of the 55th Annual Technical Conference and Exhibition, Sept. 21-24, Dallas, Texas, pp: 10-10. DOI: 10.2118/9382-MS

Lasseter, T.J., J.R. Waggoner and L.W. Lake, 1986. Reservoir Heterogeneities and Their Influence on Ultimate Recovery. In: Reservoir Characterization, Lake, Jr., L.W. and H.B. Carroll, Academic Press, Orlando, ISBN-10: 0124340652, pp: 545-559.

Ma, S. and N.R. Morrow, 1996. Relationships between porosity and permeability for porous rocks. Proceedings of the International Symposium of the Society of Core Analysts, (SCA' 96), pp: 1-12.

MacEachern, J.A., K.L. Bann, J.P. Bhattacharya and C.D. Jr, Howell, 2005. Ichnology of Deltas: Organism Responses to the Dynamic Interplay of Rivers, Waves, Storms and Tides. 1st Edn., SEPM Special Publication, ISBN-10: 15657611, pp: 37. 
MacEachern, J.A., K.L. Bann, M.K. Gingras, J.P. Zonneveld and S.E. Dashtgard et al., 2012. Chapter 4-the ichnofacies paradigm. Develop. Sedimentol., 64: $103-138$. DOI: $10.1016 /$ B978-0-444-53813-0.00004-6

Mohaghegh, S., B. Balan and S. Ameri, 1997. Permeability determination from well log data. Proceedings of the SPE Eastern Regional Conference and Exhibition, Sept. 17-21, Morgantown West Virgina, pp: 1-5.

Morris, A.P., K. Smart, D.A. Ferrill, N. Reish and P.F. Cowell, 2012. Fault compartmentalization in a mature clastic reservoir: An example from elk hills field, California. Search and Discovery.

Nichols, G., 2009. Sedimentology and Stratigraphy. 2nd Edn., Wiley, Chichester, ISBN-10: 144431193X, pp: 432.

Nwajide, C.S., 2013. Geology of Nigeria's Sedimentary Basins. 1st Edn., CSS Books Ltd, Lagos, pp: 565.

Nwozor, K.K. and L.O. Onuorah, 2014. Geopressure analysis and reservoir fluid discrimination in a central swamp field, Niger delta, Nigeria. Petroleum Coal, 56: 124-140.

O'connor, S.A., R.E. Swarbrick, B. Pindar, O.S. Ogunkoya and O. Lucas et al., 2013. Regional pressure studies in the Niger delta-their role in safe, cost effective well planning and the generation of new exploration opportunities. Proceedings of the 1st EAGE West Africa Workshop on Subsurface Challenge, (WSC' 13), West Africa. DOI: $10.3997 / 2214-4609.20131772$

Opara, A.I., 2011. Estimation of multiple sources of overpressures using vertical effective stress approach: Case study of the Niger Delta, Nigeria. Petroleum Coal, 53: 302-314.

Orlov, M.L., 1996. Multiple linear regression analysis using Microsoft excel. Department of Chemistry, Oregon State University.

Oyanyan, R.O. and M.N. Oti, 2015a. Sedimentology and ichnology of late Oligocene delta front reservoir sandstone deposit, greater ughelli depobelt, Niger delta. Am. J. Geosci., 5: 12-25.

DOI: 10.3844 /ajgsp.2015.12.25

Oyanyan, R.O. and M.N. Oti, 2015b. Down-dip cross sectional variability in sedimentological and petrophysical properties o f late Oligocene shoreface parasequence reservoir, greater ughelli depobelt, Niger delta. Petroleum Technol. Develop. J., 5: 92-117.

Pemberton, G., J. MacEachern, M. Gingras and K. Bann, 2009. Atlas of Trace Fossils. 1st Edn., Elsevier Science, Amsterdam, ISBN-10: 0444532323, pp: 300.

Pittman, E.D., 2001. Estimating pore throat size in sandstones from routine core-analysis data. AAPG Bull., 76: 191-198.
Pittman, E.D., 1992. Relationship of porosity and permeability to various parameters derived from mercury injection capillary pressure curves for sandstones. AAPG Bull., 76: 191-198. DOI: 10.1306/BDFF87A4-1718-11D7$8645000102 \mathrm{C} 1865 \mathrm{D}$

Rahimpour-Bonab, H., A.H. Enayati-Bidgoli, A. Navidtalab and H. Mehrabi, 2014. Appraisal of intra reservoir barriers in the Permo-Triassic successions of the central Persian Gulf, Offshore Iran. Geol. Acta, 12: 89-107. DOI: $10.1344 / 105.000002076$

Reijers, T.J.A., 2011. Stratigraphy and sedimentology of the Niger Delta. Geologos, 17: 133-162. DOI: $10.2478 / \mathrm{v} 10118-011-0008-3$

Rushing, J.A., K.E. Newsham and T.A. Blasingame, 2008. Rock typing: Keys to understanding productivity in tight gas sands. Proceedings of the Unconventional Resrvoirs Conference, Feb. 10-12, Keystone, Colorado, USA, pp: 1-31.

Schlumberger, 2009. Log Interpretation Chart. 1st Edn., Houston Texas, Schlumberger, pp: 310.

Shaker, S.S., 2008. Loss of circulation: Causes and consequences in geopressured systems. Proceedings of the American Association of Drilling Engineers Fluids Conference and Exhibition, (FCE' 08), Houston, Texas.

Shaker, S.S., 2014. Reservoir Vs. seal pressure gradients: Calculations and pitfalls. Proceedings of the Geoscience Technology Workshop, Deepwater Reservoirs, Jan. 28-29, Houston, Texas, pp: 1-25.

Shaker, S.S., 2012. Reservoir Vs. seal pressure gradients: Perception and pitfalls-based on case histories from the gulf of Mexico. Cseg Recorder, 04: 31-42.

Short, K.C. and A.J. Stauble, 1967. Outline of geology of Niger Delta: AAPG Bull., 51: 761-779.

Singh, V., I. Yemez and J. Sotomayor, 2013. Key factors affecting 3D reservoir interpretation and modelling outcomes: Industry perspectives. British J. Applied Sci. Technol., 3: 376-405. DOI: $10.9734 / \mathrm{BJAST} / 2014 / 3089$

Smalley, P.C. and A.H. Muggeridge, 2010. Reservoir Compartmentalization: Get it before it Gets you. In: Reservoir Compartmentalization. Jolley, S.J., Q.J. Fisher, R.B. Ainsworth, P.J. Vrolijk and S. Delisle (Eds.), Geological Society of London, London, ISBN-10: 1862393168, pp: 25-41.

Svirsky, D., A. Ryazanov, M. Pankov, P.W.M. Corbett and U. Herriot-Watt et al., 2004. Hydraulic flow units resolve description challenges in a Siberian oil field. Proceedings of the SPE Asia Pacific Conference on Integrated Modelling for Asset Management, (MAM' 04), Kualar Lumpur, Malaysia, pp: 1-15. DOI: 10.2118/87056-MS 
Taylor, A.M. and R. Goldring, 1993. Description and analysis of bioturbation and ichnofabric. J. Geol. Society, 150: 141-148. DOI: 10.1144/gsjgs.150.1.0141

Torres, H.A., H.C. Aguayo, M.M. Lea, J.B. Monjaras and P.P. Eric et al., 2010. Anisotropy and petrophysics of a gas reservoir in a horizontal well with a high angle pilot well, Burgos basin, Mexico. AAPG.

Weber, K.J., 1986. How Heterogeneity Affects Oil Recovery. In: Reservoir Characterization. Lake, L.W. and H.B. Carroll Jr. (Eds.), Academic Press, London, ISBN-10: 0124340652, pp: 487-544.
Weber, K.J., 1971. Sedimentological aspects of oil fields in Niger Delta. Geol. En Mijnbouw, 50: 559-576.

Wendt, W.A., S. Sakurai and P.H. Nelson, 1986. Permeability Prediction from Well Logs using Multiple Regression. In: Reservoir Characterization. Lake, L.W. and H.B. Carroll Jr. (Eds.), Academic Press, London, ISBN-10: 0124340652, pp: 487-544. Yielding, G. B. Freeman and D.T. Needham, 1997. Quantitative fault seal prediction. AAPG Bulletin, 81: 897-917. 